Archives of Agriculture and Environmental Science

\title{
Shelf life and quality of Sorboti lemon as affected by different chemicals and storage temperature
}

\author{
E. Kayesh ${ }^{1^{*}}$ (D) , S. Das ${ }^{1}$, M.S. Roni ${ }^{1}$, M.M.R. Rajib ${ }^{1}$, M.M. Islam ${ }^{2}$ and H. Sultana ${ }^{1}$
}

${ }^{1}$ Department of Horticulture, ${ }^{2}$ Department of Agronomy, Bangabandhu Sheikh Mujibur Rahaman Agricultural University, Salna, Gaipur-1706, BANGLADESH

"Corresponding author's E-mail: e.kayesh@yahoo.com

\section{ARTICLE HISTORY}

Received: 13 August 2018

Revised received: 22 August 2018

Accepted: 26 August 2018

\section{Keywords}

Kinetin treatment

Maximum juice content

Minimum fruit decay

Shelf life

Storage temperature

Sorboti lemon

\begin{abstract}
A laboratory experiment was conducted with different chemicals and storage temperature (Kinetin $+4^{\circ} \mathrm{C}$, kinetin $+15^{\circ} \mathrm{C}$, kinetin $+25^{\circ} \mathrm{C}$, potash alum $+4^{\circ} \mathrm{C}$, potash alum $+15^{\circ} \mathrm{C}$, potash alum $+25^{\circ} \mathrm{C}$, hot water $+4^{\circ} \mathrm{C}$, hot water $+15^{\circ} \mathrm{C}$, hot water $+25^{\circ} \mathrm{C}$, without treatment $+4^{\circ} \mathrm{C}$, without treatment $+15^{\circ} \mathrm{C}$ and without treatment $+25^{\circ} \mathrm{C}$ ) at the department of Horticulture of Bangabandhu Sheikh Mujibur Rahaman Agricultural University during June to December 2017. The aim was the study to find out the suitable method to increase shelf life of Sorboti lemon. During storage fruit decay, weight loss and total soluble solid (TSS) increased. While juice content, ascorbic acid content decreased with the increase in storage temperature. Minimum fruit decay (50\%) was recorded up to 70 Days after storage (DAS) at $4^{\circ} \mathrm{C}$ in hot water treatment and fruit decayed $(90 \%)$ at $4^{\circ} \mathrm{C}$ was recorded up to 70 DAS in Kinetin treatment. Minimum loss of fruit weight was recorded at $4^{\circ} \mathrm{C}(7.10 \%$ and $11.95 \%)$ at 70 DAS when stored in hot water and kinetin, respectively. Maximum juice content (50.11\%) after 70 DAS at $4^{\circ} \mathrm{C}$ in hot water treatment which was followed by Kinetin treatment storage at $4^{\circ} \mathrm{C}(40.10 \%)$. The TSS was found almost static at 70 days after storage but ascorbic acid content decreased (59.59 $\mathrm{mg} / 100 \mathrm{ml}$ to $43.36 \mathrm{mg} / 100 \mathrm{ml}$ and $63.10 \mathrm{mg} / 100 \mathrm{ml}$ to $49.11 \mathrm{mg} / 100 \mathrm{ml}$ ) from its initial content in hot water and kinetin at $4^{\circ} \mathrm{C}$ temperature. At $15^{\circ} \mathrm{C}$ temperature, it can only possible up to 35 days. So, considering fruit decay, weight loss, TSS and juice content lemon could be stored up to $70 \mathrm{DAS}$ at $4^{\circ} \mathrm{C}$ both under hot water and kinetin treatment. Storing can be done in $35 \mathrm{DAS}$ at $15^{\circ} \mathrm{C}$ both hot water and kinetin treatment.
\end{abstract}

(C)2018 Agriculture and Environmental Science Academy

Citation of this article: Kayesh, E., Das, S., Roni, M.S., Rajib, M.M.R., Islam, M.M. and Sultana, H. (2018). Shelf life and quality of Sorboti lemon as affected by different chemicals and storage temperature. Archives of Agriculture and Environmental Science, 3(3): 304-309, https://dx.doi.org/10.26832/24566632.2018.0303014

\section{INTRODUCTION}

The lemon is a non-climacteric fruit with relatively low respiration and ethylene production rates do not undergo any major softening or compositional changes after harvest and therefore, can normally be stored for relatively long periods (Kader, 2002). Bangladesh stands in a very low position in respect of the production of citrus fruits in comparison to other citrus producing countries of the world. According to the available statistics, the total area under these fruits is 4230 acres while total production is $63330 \mathrm{M}$. tons in the year 2011-2012 (BBS, 2013).
Lemon contains large quantity of citric acid $4.52 \%$ to $5.82 \%$. It is one of the most important fruits in international trade as fresh fruit and processed product. Roughly, $10 \%$ of the citrus produced in the world enters into international trade as fresh fruits. With globalization of world trade organization (WTO) the export opportunities of citrus fruits increase significantly. Therefore, citrus grower faced increase competition in the world market.

A considerable proportion of lemon fruit is spoiled each year due to lack of proper storage and marketing infrastructures. Hence, adequate measures should be taken to prolong shelf life 
of lemon. Storage is essential for extending the consumption period of fruits, regulating their supply to the market and also for transportation to long distances. The mature green fruits can be kept at room temperature for about 12 to15 days depending upon the variety (Carrillo et al., 2000). Shelf life of fruits could be extended by precooling, chemical treatments, low temperature, different botanical extracts, and so on. However, perforated low -density polyethylene (LDPE) linings have also been found beneficial as this material maintains humidity, which results in less shrinkage during storage (Tharanathan et al., 2006).

The combination of modified atmospheric packaging (MAP) with effective decay control measures can extend the postharvest life of fruits (Rodov et al., 1997). Storage life of fruits is affected by storage temperature because higher temperature increases respiration rate, leading to fruit softening, and at low temperature, storage metabolism is retarded by a reduction in respiration rate, color changes and softening (Perez et al., 2004). Due to mishandling, inadequate storage or lack of postharvest technical knowledge, producers and traders have to face about $27 \%$ losses (Hassan, 2010). Therefore, a research program was initiated to investigate the suitable easy method to increase shelf life of sorboti lemon.

\section{MATERIALS AND METHODS}

\section{Experimental design}

The experiment was conducted at the Laboratory of Horticulture Department, Bangabandhu Sheikh Mujibur Rhaman Agricultural University, Gazipur during the period from June 2016 to December 2016. Fruits of Sorboti lemon were treated with Kinetin, Hot water and Potash alum. The treated fruits were stored in cool chamber temperature at $4^{\circ} \mathrm{C}, 15^{\circ} \mathrm{C}$ and $25^{\circ}$ $\mathrm{C}$ packing with $0.5 \mathrm{~mm}$ polythene bag. Fresh mature fruits were harvested from Shibpur, Norshingdhi and transported in the Bangabandhu Sheikh Mujibur Rhaman Agricultural University, Gazipur with pickup. The fruits were thoroughly washed in running tap water and drying up with electric fan. The fruits were packed according to the treatment with $0.5 \mathrm{~mm}$ polythene bag. Ten fruits were packed in each polythene bag and four packed fruits were considered as one replication. Each of the fruit packets was marked with permanent marker and sealed. Then the fruit packets were stored at different temperature according to the treatments. The experiment was laid out in a completely randomized design (CRD) with three replications with 12 treatment combinations in this experiment as per the details given below:

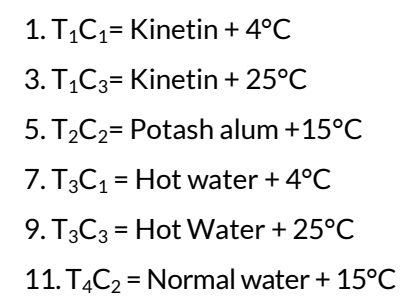

Observation and collection of data

Data were collected at fresh condition and then 7 days intervals up to 70 days. Data from four fruits of each packet were recorded. Following data were recorded during the experimental period.

\section{Fruit weight}

Weight of each fruit at the time of storage was taken in gram by electric balance and was recorded. At 7 days intervals fruit weight in gram was also recorded.

\section{Fruit decay}

Number of decay was recorded at 7 days interval and percentage was calculated from total number of fruits.

\section{Fruit weight loss}

Fruit weight loss in percentage was calculated from the initial weight and the weight was taken at 7 days interval.

\section{Juice}

Weight of juice was taken in gram by electric balance at the time of storage and recorded. At 7 days intervals juice weight in gram was also recorded. Then percent of juice was calculated.

\section{Total soluble solids}

Total soluble solid (TSS) content of lemon pulp was estimated by using a hand refractometer. One drop of lemon juice was squeezed from the fruit pulp on the prism of the refractometer (Model no. ATAGONA-Brix 0-32) and \% total soluble solid was obtained from direct reading.

\section{Vitamin C content}

The ascorbic acid content was determined as per the procedure described by Pleshkov (1976). For estimating free ascorbic acid, $10 \mathrm{ml}$ of prepared extract was taken in a conical flask. Five $\mathrm{ml}$ $5 \% \mathrm{KI}, 2 \mathrm{ml}$ of $2 \%$ starch solution, $2 \mathrm{ml}$ glacial acetic acid was added to the extract. Finally, it was titrated with $0.001 \mathrm{~N} \mathrm{KIO}_{3}$ solution. Free ascorbic acid was quantified by using the following formula:

$$
\text { Ascorbic acid content }(\mathrm{mg} / 100 \mathrm{~g})=\frac{\mathrm{TFV}}{\mathrm{vW}} \mathrm{X} 100
$$

\section{Where,}

$\mathrm{T}=$ Titrated volume of $\mathrm{KIO}_{3}(\mathrm{ml}), \mathrm{F}=0.088 \mathrm{mg}$ of ascorbic acid per $\mathrm{ml}$ of $0.001 \mathrm{NKIO}_{3}, \mathrm{~V}=$ Total volume of sample extracted $(\mathrm{ml}), \mathrm{v}=$ Volume of the extract $(\mathrm{ml})$ taken for titration, $\mathrm{W}=$ Weight of the sample taken.
Statistical analysis
The recorded data for different characters were analyzed statisti- cally using MSTAT-C program. Coefficient of variation (CV) was estimated according to Gomez and Gomez (1984). Mean separa- tion was done by using Duncan Multiple Range Test (DMRT). 


\section{RESULTS AND DISCUSSION}

\section{Fruit decay}

The loss of fruit decay was observed the highest in control and the lowest in hot water treatment (Table 1). This decay was significantly higher in kinetin compared to hot water treatment and it was also higher in potash alum treatment. Varit and Songsin (2011) concluded that the storage life of lemon dipped in hot water $\left(45^{\circ} \mathrm{C}\right.$ for $15 \mathrm{~min}$ or $50^{\circ} \mathrm{C}$ for $10 \mathrm{~min}$ ) was significantly extended. The best fruit overall quality was obtained at $50^{\circ} \mathrm{C}$ for $10 \mathrm{~min}$.

If temperature is increase than fruit decay is increase. In $25^{\circ} \mathrm{C}$ temperature, without treatment and potash alum treatment lemon can survive in 14 days after storage (DAS). In hot water treatment and kinetin treatment at $25^{\circ} \mathrm{C}$ temperature the lemon could survive in 21 DAS at $60 \%$ and $100 \%$ decay 28 DAS. At $15^{\circ} \mathrm{C}$ temperature in hot water treatment's percent of fruit decay was lower than any other treatment. In this temperature without treatment fruit can survive 28 DAS and potash alum it can be survive 28 DAS. Cooling at $15^{\circ} \mathrm{C}$ of Alphonso mango fruits increased the shelf life of the mango. Pre-cooling has been found to reduce the occurrence and intensity of spongy tissue. At $4{ }^{\circ} \mathrm{C}$ temperature without treatment $80 \%$ fruit decay in 42 DAS, the potash alum treatment 75 percent fruit decay in those DAS. In this temperature Kinetin and hot water treated fruit survive in 70 DAS. The fruit decay in 70 DAS kinetin is higher than hot water treatment. Fruit decay at 70 DAS in hot water was $50 \%$ and kinetin was $90 \%$. Percent of fruit decay in hot water treatment was lower than kinetin treatment. Similar findings in relation to shelf life extension of mango using low temperature were reported by Hassan et al. (1998). These results of extending shelf life of mango using low temperature and modified atmosphere are in support that fungal diseases constitute one of the main causes of loss during commercialization of tropical fruits. Lemon fruit can be stored for 70 DAS at $4^{\circ} \mathrm{C}$ with the compensation of $50 \%$ fruit decay and it was $65 \%$ at $15^{\circ} \mathrm{C}$ when treated with hot water treatment. This compensation was $90 \%$ at $4^{\circ} \mathrm{C}$ in kinetin solution. Among those, Hot water helps in minimum exchange of gaseous substance during storage with minimum fruit decay.

Table 1. Effect of source of materials and storage conditions on percent fruit decay of lemon in Bangladesh.

\begin{tabular}{|c|c|c|c|c|c|c|c|c|c|c|}
\hline \multirow{2}{*}{$\begin{array}{l}\text { Treatment/ } \\
\text { Combinations }\end{array}$} & \multicolumn{10}{|c|}{ Fruit decay (\%) } \\
\hline & 7 DAS & 14 DAS & 21 DAS & 28 DAS & 35 DAS & 42 DAS & 49 DAS & 56 DAS & 63 DAS & 70 DAS \\
\hline $\mathrm{T}_{1} \mathrm{C}_{1}$ & $10.00 a$ & 15.00c & $20.00 \mathrm{de}$ & 25.00de & 35.00de & $38.33 d$ & $60.00 \mathrm{~b}$ & $80.00 a$ & $85.00 a$ & $90.00 a$ \\
\hline $\mathrm{T}_{1} \mathrm{C}_{2}$ & $10.00 a$ & $15.00 \mathrm{c}$ & $50.00 c$ & $75.00 c$ & $80.00 b$ & 100.0a & - & - & - & - \\
\hline $\mathrm{T}_{1} \mathrm{C}_{3}$ & $10.00 \mathrm{a}$ & $30.00 a$ & $60.00 b$ & 100.0a & 100.0a & - & - & - & - & - \\
\hline $\mathrm{T}_{2} \mathrm{C}_{1}$ & $5.000 \mathrm{~b}$ & $10.00 d$ & 15.00ef & 25.00de & $45.00 d$ & $75.00 c$ & 100.0a & - & - & - \\
\hline $\mathrm{T}_{2} \mathrm{C}_{2}$ & $10.00 \mathrm{a}$ & $20.00 b$ & $25.00 d$ & $85.00 \mathrm{~b}$ & 100.0a & - & - & - & - & - \\
\hline $\mathrm{T}_{2} \mathrm{C}_{3}$ & $10.00 a$ & $20.00 b$ & 100.0a & - & - & - & - & - & - & - \\
\hline $\mathrm{T}_{3} \mathrm{C}_{1}$ & $0.000 c$ & $10.00 \mathrm{~d}$ & 15.00ef & $20.00 e$ & $25.00 \mathrm{e}$ & $30.00 \mathrm{e}$ & $35.00 c$ & $40.00 b$ & $50.00 \mathrm{~b}$ & $50.00 \mathrm{~b}$ \\
\hline $\mathrm{T}_{3} \mathrm{C}_{2}$ & $5.000 \mathrm{~b}$ & $5.000 \mathrm{e}$ & $10.00 f$ & $30.00 d$ & $65.00 \mathrm{c}$ & 100.0a & - & - & - & - \\
\hline $\mathrm{T}_{3} \mathrm{C}_{3}$ & $5.000 \mathrm{~b}$ & $10.00 d$ & $60.00 \mathrm{~b}$ & $100.0 a$ & - & - & - & - & - & - \\
\hline $\mathrm{T}_{4} \mathrm{C}_{1}$ & $10.00 \mathrm{a}$ & $15.00 \mathrm{c}$ & 20.00de & 25.00de & $26.00 \mathrm{e}$ & $80.00 \mathrm{~b}$ & 100.0a & - & - & - \\
\hline $\mathrm{T}_{4} \mathrm{C}_{2}$ & $10.00 \mathrm{a}$ & $30.00 a$ & $55.00 b c$ & $90.00 \mathrm{~b}$ & 100.0a & - & - & - & - & - \\
\hline $\mathrm{T}_{4} \mathrm{C}_{3}$ & $5.000 \mathrm{~b}$ & $15.00 \mathrm{c}$ & $100.0 \mathrm{a}$ & - & - & - & - & - & - & - \\
\hline CV (\%) & 8.91 & 9.89 & 7.71 & 8.50 & 13.92 & 7.38 & 16.23 & 9.13 & 6.42 & 13.32 \\
\hline $\begin{array}{c}\text { Level of } \\
\text { significance }\end{array}$ & $* *$ & $* *$ & $* *$ & $* *$ & $* *$ & $* *$ & $* *$ & $* *$ & $* *$ & $* *$ \\
\hline
\end{tabular}

Means in a column followed by the same letters are not significantly different at $1 \%$ level of significant; ${ }^{* *}=$ Significant at $1 \%$ level of probability; $T_{1}=$ Kinetin, $\mathrm{T}_{2}=$ Potash; Alum, $\mathrm{T}_{3}=$ Hot water and $\mathrm{T}_{4}=$ Normal water $\mathrm{C}_{1}=4^{\circ} \mathrm{C}, \mathrm{C}_{2}=15^{\circ} \mathrm{C}$ and $\mathrm{C}_{3}=25^{\circ} \mathrm{C}$

Table 2. Effect of different treatment and storage conditions on percent weight loss of Sorboti lemon in Bangladesh.

\begin{tabular}{|c|c|c|c|c|c|c|c|c|c|c|}
\hline \multirow{2}{*}{$\begin{array}{l}\text { Treatment/ } \\
\text { Combinations }\end{array}$} & \multicolumn{10}{|c|}{ Weight loss (\%) } \\
\hline & 7 DAS & 14 DAS & 21 DAS & 28 DAS & 35 DAS & 42 DAS & 49 DAS & 56 DAS & 63 DAS & 70 DAS \\
\hline $\mathrm{T}_{1} \mathrm{C}_{1}$ & $1.180 f$ & $3.220 \mathrm{e}$ & $4.560 \mathrm{de}$ & $5.390 \mathrm{e}$ & $6.87 c$ & $7.410 c$ & $8.330 a$ & $10.30 \mathrm{a}$ & $12.50 a$ & $11.95 a$ \\
\hline $\mathrm{T}_{1} \mathrm{C}_{2}$ & $3.750 c$ & $5.690 \mathrm{c}$ & $7.520 c$ & $8.990 a$ & $9.90 a$ & - & - & - & - & - \\
\hline $\mathrm{T}_{1} \mathrm{C}_{3}$ & $4.210 \mathrm{~b}$ & $0.260 \mathrm{~g}$ & $9.590 \mathrm{~b}$ & - & - & - & - & - & - & - \\
\hline $\mathrm{T}_{2} \mathrm{C}_{1}$ & $1.110 f$ & 2.650 ef & 4.010ef & $5.990 d$ & $6.21 \mathrm{c}$ & $8.560 \mathrm{~b}$ & - & - & - & - \\
\hline $\mathrm{T}_{2} \mathrm{C}_{2}$ & $1.260 f$ & $1.870 f$ & $3.210 f$ & $4.180 f$ & - & - & - & - & - & - \\
\hline $\mathrm{T}_{2} \mathrm{C}_{3}$ & $3.610 c$ & $7.150 \mathrm{~b}$ & - & - & - & - & - & - & - & - \\
\hline $\mathrm{T}_{3} \mathrm{C}_{1}$ & $0.670 \mathrm{~g}$ & $0.330 \mathrm{~g}$ & $1.360 \mathrm{~g}$ & $1.800 \mathrm{~g}$ & $2.70 \mathrm{~d}$ & $3.410 d$ & $4.900 b$ & $5.390 b$ & $6.250 \mathrm{~b}$ & $7.100 b$ \\
\hline $\mathrm{T}_{3} \mathrm{C}_{2}$ & $2.980 d$ & $4.690 \mathrm{~cd}$ & $6.710 c$ & $8.250 b$ & $8.28 b$ & - & - & - & - & - \\
\hline $\mathrm{T}_{3} \mathrm{C}_{3}$ & $3.720 c$ & $7.510 \mathrm{~b}$ & $11.10 \mathrm{a}$ & - & - & - & - & - & - & - \\
\hline $\mathrm{T}_{4} \mathrm{C}_{1}$ & $1.910 \mathrm{e}$ & 3.720de & $5.060 d$ & $7.310 c$ & $9.92 a$ & $10.15 a$ & - & - & - & - \\
\hline $\mathrm{T}_{4} \mathrm{C}_{2}$ & $3.060 d$ & $5.430 c$ & $7.700 c$ & $8.150 b$ & - & - & - & - & - & - \\
\hline $\mathrm{T}_{4} \mathrm{C}_{3}$ & $5.220 \mathrm{a}$ & $12.90 a$ & - & - & - & - & - & - & - & - \\
\hline CV (\%) & 5.89 & 14.08 & 11.68 & 7.83 & 7.68 & 5.12 & 9.03 & 7.96 & 10.33 & 2.57 \\
\hline $\begin{array}{c}\text { Level of } \\
\text { significance }\end{array}$ & $* *$ & $* *$ & $* *$ & $* *$ & $* *$ & $* *$ & $* *$ & $* *$ & $* *$ & $* *$ \\
\hline
\end{tabular}

Means in a column followed by the same letters are not significantly different at $1 \%$ level of significant; ${ }^{* *}=$ Significant at $1 \%$ level of probability; $\mathrm{T}_{1}=$ Kinetin, $\mathrm{T}_{2}=$ Potash Alum, $\mathrm{T}_{3}=$ Hot water and $\mathrm{T}_{4}=$ Normal water $; \mathrm{C}_{1}=4^{\circ} \mathrm{C}, \mathrm{C}_{2}=15^{\circ} \mathrm{C}$ and $\mathrm{C}_{3}=25^{\circ} \mathrm{C}$ 
Weight loss

Postharvest storage treatments used in the present investigation showed effects on total weight loss of lemon during storage. Variation among the treatment means in respect of total weight loss was highly significant at all dates of observation. According (Table 2) $4^{\circ} \mathrm{C}$ temperature weight loss was lowest in hot water treatment compare than without treatment. Lemon storage life is high in hot water treatment and kinetin treatment. The hot water treatment (7.10\%) lemon had lowest water loss compare to kinetin treatment (11.95\%). This reduction in weight loss due to low temperature coupled with high humidity could be attributed to the reduction in respiration as well as transpiration rate at lower temperatures (Ramana et al., 1984).

The weight loss was increasing with the increasing of storage temperature at $35 \mathrm{DAS}$. At, $15^{\circ} \mathrm{C}$ maximum weight loss was observed in kinetin treated lemon at $52 \%$, in this same temperature hot water treated lemon weight loss was $47 \%$. Haque (1985) also reported the similar results. He reported that the weight loss of bananas occurred due to the loss of water from the fruits, microbial decay and storage environment like temperature and humidity. At $25^{\circ} \mathrm{C}$ temperature weight loss was higher than any other treatment. In this temperature without treated lemon weight loss was higher than any other treatment. At $25^{\circ} \mathrm{C}$ temperature weight loss was lower than any other treatment. If we want to keep lemon in room temperature than kinetin treatment will be the best than any other treatments because at room temperature kinetin treated lemon weight loss was lower than other. But if we want in $4^{\circ} \mathrm{C}$ temperature than hot water treatment will be the best. Weight loss continued to increase with prolonged storage duration so that each 15 days interval caused significant increase in cumulative weight loss. The weight loss increased to the maximum of (8.57\%) with 75 days storage (Rab et al., 2015).

\section{Juice content}

The highest juice content was observed in the lemon of hot water treatment and the lowest without treatment at 7 DAS.
According to (Table 3 ) the juice content was decreasing with an increase in storage temperature. After 70 DAS of storage maximum juice content was observed in hot water treated lemon. The juice content in hot water treatment at 70 DAS was $50.11 \%$ and kinetin treatment was 40.10\%. Joseph and Aworh (1992) observed that mature green fruits dipped in hot water at $55^{\circ} \mathrm{C}$ delayed ripening, controlled decay, minimized weight loss and extended shelf life of fruits without adverse effects on visual or chemicals. Nyalala and Wainwright (1998) studied the shelf life of two tomato cultivars (Money Maker and Calaj) stored at $4.5^{\circ} \mathrm{C}$, room temperature $\left(18-25^{\circ} \mathrm{C}\right.$ ) and $30^{\circ} \mathrm{C}$. They observed that weight loss was significantly higher at increased temperatures and there was an interaction between cultivar and temperature. They also observed that, loss of fruit firmness was greatest less than two higher temperatures, but there was on significant difference between the cultivars. The juice content was highest in $4^{\circ} \mathrm{C}$ temperature at hot water treated lemon.

\section{Total soluble solid (TSS)}

Total soluble solid of lemon increased with the duration of storage. The postharvest treatments used in the present study exhibited pronounced effect on total soluble solid of lemon during storage and it was statistically significant. At 7 DAS the TSS was highest in control (Table 4). It was 6.20 at $25^{\circ} \mathrm{C}$. At 7 DAS hot water treated lemon TSS was $5.40 \%$ and it increased day by day. At 70 DAS the TSS was $8.70 \%$. In 7 DAS kinetin treated lemon was contain TSS $5.20 \%$ and 70 DAS it was convert in $8.40 \%$. This may be due to increase in senescence process which resulted in increased respiration rate. The decrease in moisture content was probably due to transpiration and evaporation losses of water including hydrolysis of starch. This increase in TSS content is due to the conversion of complex carbohydrates into simple sugars. This is correlated with hydrolytic changes in starch and conversion of starch to sugar being an important index of ripening process in mango and other climacteric fruits and further hydrolysis decreased the TSS content during storage (Kays, 1991; Kittur et al., 2001).

Table 3. Effect of different treatment and storage conditions on percent juice content of Sorboti lemon in Bangladesh.

\begin{tabular}{|c|c|c|c|c|c|c|c|c|c|c|}
\hline \multirow{2}{*}{$\begin{array}{l}\text { Treatment/ } \\
\text { Combinations }\end{array}$} & \multicolumn{10}{|c|}{ Juice content (\%) } \\
\hline & 7 DAS & 14 DAS & 21 DAS & 28 DAS & 35 DAS & 42 DAS & 49 DAS & 56 DAS & 63 DAS & 70 DAS \\
\hline $\mathrm{T}_{1} \mathrm{C}_{1}$ & $56.20 b c$ & $54.93 b$ & $53.10 b$ & $51.90 b$ & $50.57 \mathrm{~b}$ & $49.78 b$ & $47.60 \mathrm{~b}$ & $45.69 \mathrm{~b}$ & $44.00 b$ & $40.10 b$ \\
\hline $\mathrm{T}_{1} \mathrm{C}_{2}$ & $54.30 \mathrm{e}$ & $51.62 c$ & 49.40de & $46.23 d$ & $41.72 f$ & - & - & - & - & - \\
\hline $\mathrm{T}_{1} \mathrm{C}_{3}$ & $51.76 \mathrm{~g}$ & $48.89 d$ & $44.47 f$ & - & - & - & - & - & - & - \\
\hline $\mathrm{T}_{2} \mathrm{C}_{1}$ & 56.87ab & 55.73ab & $53.00 \mathrm{~b}$ & $50.99 b c$ & 49.11c & - & - & - & - & - \\
\hline $\mathrm{T}_{2} \mathrm{C}_{2}$ & $55.60 \mathrm{~cd}$ & $54.95 b$ & $54.05 b$ & $52.90 \mathrm{~b}$ & - & - & - & - & - & - \\
\hline $\mathrm{T}_{2} \mathrm{C}_{3}$ & $52.91 f$ & $48.58 d$ & - & - & - & - & - & - & - & - \\
\hline $\mathrm{T}_{3} \mathrm{C}_{1}$ & $57.47 a$ & $56.92 a$ & $56.31 \mathrm{a}$ & $55.84 a$ & $54.36 a$ & $54.12 \mathrm{a}$ & $52.80 \mathrm{a}$ & $51.97 a$ & $50.99 a$ & $50.11 a$ \\
\hline $\mathrm{T}_{3} \mathrm{C}_{2}$ & $56.77 \mathrm{~b}$ & $54.55 b$ & $52.36 b c$ & $49.11 \mathrm{c}$ & 44.17e & - & - & - & - & - \\
\hline $\mathrm{T}_{3} \mathrm{C}_{3}$ & $54.61 e$ & $49.39 d$ & $42.83 f$ & - & - & - & - & - & - & - \\
\hline $\mathrm{T}_{4} \mathrm{C}_{1}$ & $55.37 d$ & $54.47 b$ & $51.07 \mathrm{~cd}$ & $49.18 c$ & $46.99 d$ & $45.19 c$ & - & - & - & - \\
\hline $\mathrm{T}_{4} \mathrm{C}_{2}$ & $53.17 f$ & $50.11 d$ & 48.90e & $45.38 d$ & - & - & - & - & - & - \\
\hline $\mathrm{T}_{4} \mathrm{C}_{3}$ & $50.12 \mathrm{~h}$ & $40.19 e$ & - & - & - & - & - & - & - & - \\
\hline CV (\%) & 0.71 & 1.63 & 2.49 & 3.58 & 2.95 & 2.68 & 8.98 & 4.26 & 11.78 & 4.25 \\
\hline $\begin{array}{c}\text { Level of } \\
\text { significance }\end{array}$ & $* *$ & $* *$ & $* *$ & $* *$ & $* *$ & $* *$ & $* *$ & $* *$ & $* *$ & $* *$ \\
\hline
\end{tabular}

Means in a column followed by the same letters are not significantly different at $1 \%$ level of significant; ${ }^{* *}=$ Significant at $1 \%$ level of probability; $\mathrm{T}_{1}=$ Kinetin, $\mathrm{T}_{2}=$ Potash Alum, $\mathrm{T}_{3}=$ Hot water and $\mathrm{T}_{4}=$ Normal water; $\mathrm{C}_{1}=4^{\circ} \mathrm{C}, \mathrm{C}_{2}=15^{\circ} \mathrm{C}$ and $\mathrm{C}_{3}=25^{\circ} \mathrm{C}$ 
Ascorbic acid

The ascorbic acid content of lemon was significantly affected by different treatments. In increasing the storage period the ascorbic acid was decreases. It decrease might be due to its degradation (Table 5). The lowest ascorbic acid was observed in hot water treated lemon at $4^{\circ} \mathrm{C}$ temperature storage. After 70 DAS the vitamin $C$ was low at hot water treated lemon but it was high in kinetin treated lemon. At kinetin treated lemon ascorbic acid was $49.11 \mathrm{mg} / 100 \mathrm{~g}$ but hot water treated lemon it was 43.36 $\mathrm{mg} / 100 \mathrm{~g}$. At kinetin treated lemon ascorbic acid consistence was higher than any other treatment. Ascorbic acid is an extremely unstable water-soluble vitamin. The ascorbic acid content of foods can be reduced by exposure to extreme cold, heat, light, lengthy storage and water. Ascorbic acid is found in citrus fruits, berries, and in vegetables such as broccoli and spinach. All forms of cooking reduce ascorbic acid levels in foods. However, boiling foods destroys the highest percentage. In a study published in the August 2009 issue of the "Journal of Zhejiang University Science," researchers examined five methods of cooking broccoli. The methods were stir-frying, microwaving, steaming, boiling, and a combination of stir-frying and boiling. The study concluded that after five minutes of cooking broccoli florets, using each method, boiling destroyed the highest percentage of ascorbic acid.

Table 4. Effect of different treatment and storage conditions on total soluble solid (TSS) of Sorboti lemon in Bangladesh.

\begin{tabular}{|c|c|c|c|c|c|c|c|c|c|c|}
\hline \multirow{2}{*}{$\begin{array}{l}\text { Treatment/ } \\
\text { Combinations }\end{array}$} & \multicolumn{10}{|c|}{ Total soluble solid (\%) } \\
\hline & 7 DAS & 14 DAS & $21 \mathrm{DAS}$ & 28 DAS & 35 DAS & 42 DAS & 49 DAS & 56 DAS & 63 DAS & 70 DAS \\
\hline $\mathrm{T}_{1} \mathrm{C}_{1}$ & 5.200ef & $6.500 c$ & $6.800 c$ & $7.000 \mathrm{~b}$ & $7.100 c$ & $7.200 b$ & $7.400 b$ & $7.800 \mathrm{~b}$ & $8.100 b$ & $8.400 b$ \\
\hline $\mathrm{T}_{1} \mathrm{C}_{2}$ & $5.600 \mathrm{~cd}$ & $6.600 b c$ & $7.100 b$ & $7.400 a$ & $7.900 a$ & - & - & - & - & - \\
\hline $\mathrm{T}_{1} \mathrm{C}_{3}$ & $5.800 b c$ & 6.800ab & $7.700 a$ & - & - & - & - & - & - & - \\
\hline $\mathrm{T}_{2} \mathrm{C}_{1}$ & $5.100 f$ & $5.900 \mathrm{e}$ & 6.200de & $6.900 \mathrm{~b}$ & $7.100 c$ & $7.600 \mathrm{a}$ & - & - & - & - \\
\hline $\mathrm{T}_{2} \mathrm{C}_{2}$ & 5.200ef & $5.700 \mathrm{e}$ & 6.100ef & $7.100 b$ & - & - & - & - & - & - \\
\hline $\mathrm{T}_{2} \mathrm{C}_{3}$ & $6.000 a b$ & $6.200 d$ & - & - & - & - & - & - & - & - \\
\hline $\mathrm{T}_{3} \mathrm{C}_{1}$ & 5.400de & 6.000de & $6.400 d$ & $6.900 \mathrm{~b}$ & $7.200 b c$ & 7.600a & 7.900a & $8.100 a$ & $8.600 a$ & $8.700 a$ \\
\hline $\mathrm{T}_{3} \mathrm{C}_{2}$ & $5.600 \mathrm{~cd}$ & $5.800 \mathrm{e}$ & 6.100ef & $6.900 \mathrm{~b}$ & $7.400 b$ & - & - & - & - & - \\
\hline $\mathrm{T}_{3} \mathrm{C}_{3}$ & $6.100 \mathrm{a}$ & 6.800ab & $7.300 \mathrm{~b}$ & - & - & - & - & - & - & - \\
\hline $\mathrm{T}_{4} \mathrm{C}_{1}$ & $5.200 \mathrm{ef}$ & $5.400 f$ & $5.900 f$ & $6.300 c$ & $6.800 d$ & $6.900 c$ & - & - & - & - \\
\hline $\mathrm{T}_{4} \mathrm{C}_{2}$ & $5.500 d$ & $5.900 \mathrm{e}$ & $6.200 \mathrm{de}$ & $6.900 \mathrm{~b}$ & - & - & - & - & - & - \\
\hline $\mathrm{T}_{4} \mathrm{C}_{3}$ & $6.200 \mathrm{a}$ & 7.000a & - & - & - & - & - & - & - & - \\
\hline CV (\%) & 2.26 & 2.59 & $6.800 c$ & 3.25 & 3.38 & 2.64 & 9.34 & 4.87 & 4.64 & 9.06 \\
\hline $\begin{array}{c}\text { Level of } \\
\text { significance }\end{array}$ & $* *$ & $* *$ & $* *$ & $* *$ & $* *$ & $* *$ & $* *$ & $* *$ & $* *$ & $* *$ \\
\hline
\end{tabular}

Means in a column followed by the same letters are not significantly different at $1 \%$ level of significant; ${ }^{* *}=$ Significant at $1 \%$ level of probability; $\mathrm{T}_{1}=$ Kinetin, $\mathrm{T}_{2}=$ Potash Alum, $\mathrm{T}_{3}=$ Hot water and $\mathrm{T}_{4}=$ Normal water $; \mathrm{C}_{1}=4^{\circ} \mathrm{C}, \mathrm{C}_{2}=15^{\circ} \mathrm{C}$ and $\mathrm{C}_{3}=25^{\circ} \mathrm{C}$

Table 5. Effect of different treatment and storage conditions on ascorbic acid of Sorboti lemon in Bangladesh.

\begin{tabular}{|c|c|c|c|c|c|c|c|c|c|c|}
\hline \multirow{2}{*}{$\begin{array}{l}\text { Treatment/ } \\
\text { Combinations }\end{array}$} & \multicolumn{10}{|c|}{ Ascorbic acid (mg/100g) } \\
\hline & 7 DAS & 14 DAS & 21 DAS & 28 DAS & 35 DAS & 42 DAS & 49 DAS & 56 DAS & 63 DAS & 70 DAS \\
\hline $\mathrm{T}_{1} \mathrm{C}_{1}$ & 63.10 & $62.00 \mathrm{a}$ & $60.87 a$ & $59.13 a$ & $57.87 a$ & $56.11 a$ & $54.93 a$ & $52.15 a$ & $50.69 a$ & $49.11 a$ \\
\hline $\mathrm{T}_{1} \mathrm{C}_{2}$ & 61.17 & $58.42 c$ & $55.87 \mathrm{~cd}$ & $53.96 \mathrm{~cd}$ & $52.90 \mathrm{~b}$ & - & - & - & - & - \\
\hline $\mathrm{T}_{1} \mathrm{C}_{3}$ & 61.39 & $59.37 b c$ & $57.18 b c$ & - & - & - & - & - & - & - \\
\hline $\mathrm{T}_{2} \mathrm{C}_{1}$ & 62.89 & $61.11 a$ & 53.06ef & 58.00ab & $56.21 a$ & - & - & - & - & - \\
\hline $\mathrm{T}_{2} \mathrm{C}_{2}$ & 61.56 & $60.00 \mathrm{~b}$ & $58.87 \mathrm{~b}$ & $56.99 \mathrm{~b}$ & - & - & - & - & - & - \\
\hline $\mathrm{T}_{2} \mathrm{C}_{3}$ & 60.97 & $59.00 b c$ & - & - & - & - & - & - & - & - \\
\hline $\mathrm{T}_{3} \mathrm{C}_{1}$ & 59.76 & $56.23 d$ & $55.96 \mathrm{~cd}$ & $54.28 c$ & $52.70 \mathrm{~b}$ & $50.20 \mathrm{~b}$ & $48.79 b$ & $46.22 b$ & $44.77 b$ & $43.36 b$ \\
\hline $\mathrm{T}_{3} \mathrm{C}_{2}$ & 58.58 & 53.78ef & $51.29 f g$ & 49.40e & $47.28 d$ & - & - & - & - & - \\
\hline $\mathrm{T}_{3} \mathrm{C}_{3}$ & 58.07 & $53.00 f$ & $50.48 \mathrm{~g}$ & $48.39 \mathrm{e}$ & - & - & - & - & - & - \\
\hline $\mathrm{T}_{4} \mathrm{C}_{1}$ & 59.69 & $56.33 d$ & 54.00de & $51.97 d$ & $49.92 c$ & $47.20 c$ & - & - & - & - \\
\hline $\mathrm{T}_{4} \mathrm{C}_{2}$ & 58.30 & $54.52 \mathrm{e}$ & $51.69 f g$ & $47.72 \mathrm{e}$ & - & - & - & - & - & - \\
\hline $\mathrm{T}_{4} \mathrm{C}_{3}$ & 58.00 & $53.29 f$ & - & - & - & - & - & - & - & - \\
\hline $\mathrm{CV}(\%)$ & 0.68 & 1.04 & 2.53 & 3.00 & 5.57 & 2.11 & 6.71 & 3.09 & 3.64 & 4.37 \\
\hline $\begin{array}{c}\text { Level of } \\
\text { significance }\end{array}$ & ns & $* *$ & $* *$ & $* *$ & $* *$ & $* *$ & $* *$ & $* *$ & $* *$ & $* *$ \\
\hline
\end{tabular}

Means in a column followed by the same letters are not significantly different at $1 \%$ level of significant; ${ }^{* *}=$ Significant at $1 \%$ level of probability $\mathrm{T}_{1}=$ Kinetin, $\mathrm{T}_{2}=$ Potash alum, $\mathrm{T}_{3}=$ Hot water and $\mathrm{T}_{4}=$ Normal water $; \mathrm{C}_{1}=4^{\circ} \mathrm{C}, \mathrm{C}_{2}=15^{\circ} \mathrm{C}$ and $\mathrm{C}_{3}=25^{\circ} \mathrm{C}$ 


\section{Conclusion}

Fruit decay, weight loss and TSS increased during storage period. While juice content, ascorbic acid content decreased with the increase in storage temperature. The lowest fruit decay and weight loss was observed in hot water treatment compare to kinetin and potash alum. But kinetin showed the highest ascorbic acid compared to other. The TSS content from 70 days after storage was found almost static. Based on fruit decay, weight loss, juice content and TSS content lemon can be stored up to 70 days after storage at $4^{\circ} \mathrm{C}$ both in hot water and kinetin. At $15^{\circ} \mathrm{C}$ temperature, it can only possible up to 35 days. So, considering fruit decay, weight loss, TSS and juice content lemon could be stored up to 70 DAS at $4^{\circ} \mathrm{C}$ both under hot water and kinetin treatment. Storing can be done in $35 \mathrm{DAS}$ at $15^{\circ} \mathrm{C}$ both hot water and kinetin treatment.

\section{ACKNOWLEDGMENT}

This work was supported by a project funded by the "Ministry of Science \& Technology" Bangladesh.

Open Access: This is open access article distributed under the terms of the Creative Commons Attribution License, which permits unrestricted use, distribution, and reproduction in any medium, provided the original author(s) and the source are credited.

\section{REFERENCES}

BBS. (2013). Statistical Pocket Book of Bangladesh, 2013. Bangladesh Bureau of Statistics, Planning Division, Ministry of Planning, Government of the People's Republic of Bangladesh, Dhaka. pp. 46.

Carrillo, L.A., Ramirez-Bustamante, F., Valdez-Torres, J.B., Rojas-Villegas, R. and Yahia, E.M. (2000). Ripening and quality changes in mango fruit as affected by coating with an edible film. Journal of Food Quality, 23: 479-486.

Gomez, K.A. and Gomez, A.A. (1984). Statistical Procedure for Agricultural Research (2 ${ }^{\text {nd }}$ edition). Willey. International Science Publication, pp. 28-192.

Haque, M.A. (1985). Ripening time and weight loss during ripening of "Amritasagar" banana. Bangladesh Journal of Agricultural Research, 10(2): 156-158.

Hassan, M.K, Mondal, M.F. and Hoque, M.S. (1998). Studies on the storage behaviour of mango. Bangladesh Journal of
Agricultural Science, 25(2): 311-318.

Hassan, M.K. (2010). Final Report: Postharvest loss Assessment: A Study to Formulate Policy for Postharvest Loss Reduction of fruits and Vegetables and Socio-Economic Uplift of the Stakeholders. pp. 188 (A Research Project Funded by USAID and EC, and Jointly implemented by FAO and FPM of the Ministry of Food and Disaster Management (MoFDM) under the National Food Programme Capacity Strengthening Programme NFPCSP).

Joseph, K. and Aworh, O.C. (1992). Postharvest treatment of wild tomato following hot water and Vapour heat treatments. Postharvest Biology Technology, 1(4): 349-359.

Kader, A.A. (2002). Postharvest Technology of Horticultural Crops. $3^{\text {rd }}$ ed. Univ. of California,

Kays, S.J. (1991). Postharvest Physiology of Perishable Plant Products. Vas Nostrand Rein Hold Book, AVI Publishing Co., pp. 149-316.

Kittur, F.S., Saroja, N., Habibunnisa, M. and Tharanathan, R.N. (2001). Polysaccharide-based composite coating formulations for shelf-life extension of fresh banana and mango. Eurpean Food Research and Technology, 213: 306-311.

Nyalala, S.P.O. and Wainwright, H. (1998). The shelf life of tomato cultivars at different storage temperatures. Tropical Science, 38(3): 151-154.

Perez, K., Mercado J. and Valdez, H.S. (2004). Effect of storage temperature on the shelf life of Hass avocado (Persea Americana). Food Science and Technology International,10: 0073-5.

Pleshkov, B.P. (1976). Practical works on plant biochemistry. Moscow, Kolos. pp. 236.

Rab, A., Najia, M., Sajid, F., Bibi, I., Jan, G., Nabi and Nawab, K. (2015). Quality changes in heat treated sweet orange fruit during storage at low temperature. The Journal of Animal \& Plant Science, 25(3): 661-668.

Ramana, K.V.R. (1984). Book of Indian Food. Packer, 38: 58-66.

Rodov, V., Fishman, S., Asuncion, R.D., Peretz, J. and Yehoshua, S.B. (1997). Modified Atmosphere Packaging (MAP) of Tommy Atkins mango in perforated film. Acta Horticulture, 455: 654-61.

Tharanathan, R.N., Yashoda H.M. and Prabha, T.N. (2006). Mango (Mangifera indica L.) The King of Fruits-An Overview. Food Reviews International, 22: 95-123.

Varit, S. and Songsin, P. (2011). Effects of hot water treatments on the physiology and quality of 'Kluai Khai' banana. International Food Research Journal, 18(3): 59-62. 